\title{
War, the state, and the formation of the North Korean industrial working class, 1931-1960
}

Owen Miller

Department of the Languages and Cultures of Japan and Korea

SOAS University of London

This work was supported by the Academy of Korean Studies under Grant AKS-2011-BAA-2104 


\begin{abstract}
This article examines how Koreans became industrial workers in the first and second phases of industrialisation on the peninsula: under Japanese colonial rule, 1931-1945, and under the DPRK's post-Korean War heavy industrialisation, 1953-1960. While the political regimes of the Japanese colony and postcolonial DPRK were different, industrialisation occurred under similar conditions, characterised principally by war, state capitalism and imperialism. Processes of proletarianisation also reveal similarities in the two periods, including the widespread use of forced mobilisation and immobilisation of workers and a bureaucratic apparatus supporting close control of labour. This article contributes to the critique of conventional views about the role of 'free wage labour' during the transition to capitalism.
\end{abstract}

\title{
Keywords
}

Korea, industrialisation, proletarianisation, wage labour, state capitalism, war 


\section{Introduction}

During the twentieth century the Korean peninsula saw three major phases of industrialisation and proletarianisation, each under very different political regimes. The first occurred in the mid to late 1930s under colonial rule as the Japanese empire made northern Korea a forward operating base for its invasion of China. The second was also focused in northern Korea during the post-Korean War period, as the Democratic People's Republic of Korea reconstructed its shattered economy and attempted to emulate Stalin's heavy-industry-first policy. The third - and best known - phase occurred in South Korea, beginning in the mid 1960s. Previous work on development on the Korean peninsula has focused almost exclusively on this last phase and the story of South Korea's rapid rise as an 'Asian Tiger', exceptionalising its development as a 'miracle'. ${ }^{i}$ This paper will instead examine the first two phases of Korean development to find out what can be learnt about the character of industrialisation and proletarianisation in mid-twentieth century East Asia. It will ask the question: how did Korean peasants become workers in the mid-twentieth century? We might assume that the answer to this question is straightforward, but even a cursory examination of the history of the last 200 years shows that the way people have become workers has varied enormously according to time and place.

While the story of North Korea's economic development has been largely overlooked, studies that cross the colonial/postcolonial divide in modern Korean history are even more unusual.

Approaching the problem of Korean proletarianisation through a transhistorical study of colonial and postcolonial northern Korea has some potential benefits for our understanding of Third World proletarianisation more generally. First, we can easily compare colonial and postcolonial regimes of industrialisation that were separated by only a short period of time. Second, we can examine two cases in which the state played a particularly clear role in proletarianisation. And third, we can consider the effects of two major wars on the processes of industrialisation and class formation. To summarise: although the political regimes of the Japanese colonial state and the postcolonial DPRK state were very different, industrialisation during these two periods occurred under similar conditions, characterised principally by war, imperialism and state capitalism. Similarities in processes of proletarianisation are therefore also apparent, with a strong tendency toward the forced mobilisation of workers to alleviate labour shortages in new industries or industries that were considered strategically important for war or postwar reconstruction. Likewise, under conditions of high-speed state capitalist development, workers were uprooted suddenly from their rural environments and thrown into dangerous industrial conditions of which they had no previous experience. Resistance to this in both periods often took the form of high worker mobility, which was countered by the state in the form of strong labour discipline and legal sanctions against moving workplace that pushed conditions for workers towards the unfree end of the wage labour spectrum. In the colonial period the new working class also created strong labour movements, but for various reasons this form of resistance was not repeated in the 1950s. ${ }^{\text {ii }}$

\section{Proletarianisation and Global Labour History}


Research on proletarianisation in the twentieth century, particularly in the newly emerging field of 'global labour history', has recognised that the process of class formation has not followed a classical model laid down by England or other western European countries. This research has also shown that forcible mobilisation played a major part in the proletarianisation of peasants in many parts of the world. But as yet there has been little attention paid to the role of the state and war in this process. In particular, the process of proletarianisation in countries where the state either directed or completely dominated the national economy has been overlooked. In the following I will look briefly at how a number of historians and theorists from Marx onwards have approached the issue of proletarianisation outside of Europe.

As is well known, Karl Marx defined the working class created by capitalism as a class that was 'free' in two senses: "neither they themselves form part and parcel of the means of production, as in the case of slaves, bondsmen, etc., nor do the means of production belong to them, as in the case of peasant-proprietors." ${ }^{\prime i i i}$ In other words, they are both free to sell their labour to an employer and free from owning significant means of production. Thus for Marx the process of proletarianisation is also a double one: of emancipating workers from the bonds of precapitalist societies (slavery, serfdom, guilds) and at the same time of "divorcing the producer from the means of production." Marx is quite clear that this is not a positive story of liberation, as liberal historians would have it, but rather a story of expropriation, "written in the annals of mankind in letters of blood and fire."'iv In chapter 27 of Capital I, Marx goes on to describe the 'classical' form that this expropriation took in England, from the enclosure of agricultural land for sheep grazing, to the appropriation of church, crown and common land by private landowners, to the clearances of great estates. This process created a ready-made army of workers for the new industries of the towns and cities of the seventeenth and eighteenth centuries, creating the conditions in which the worker is subjugated to the capitalist by the "dull compulsion of economic relations."

However, from the start, Marx recognised that this particular English experience of proletarianisation would not necessarily be the model for all others that would surely follow as capitalism spread around the globe. He writes for example, that the "history of this expropriation, in different countries, assumes different aspects, and runs through its various phases in different orders of succession, and at different periods." ${ }^{\text {vi }} \mathrm{He}$ also recognised that, while the economic relations of nascent capitalism appeared to the worker as "self-evident laws of Nature", vii coercion, and particularly state-backed coercion, were still a key element of capitalist relations of production and the process of proletarianisation:

Direct force, outside economic conditions, is of course still used, but only exceptionally. In the ordinary run of things, the labourer can be left to the "natural laws of production," .... It is otherwise during the historic genesis of capitalist production. The bourgeoisie, at its rise, wants and uses the power of the state to "regulate" wages, i.e., to force them within the limits suitable for surplus value making, to lengthen the working day and to keep the labourer himself in the normal degree of dependence. ${ }^{\text {viii }}$ 
In one of the few books to consider the general phenomenon of twentieth century proletarianisation in the non-European world, Munslow and Finch have echoed Marx, arguing that "the experience of the Third World has not been, on the whole, simply a replication of the kind of proletarianisation that occurred in Britain and the other advanced capitalist countries, with the creation of a large-scale permanent proletariat, divorced from ownership of the means of production and thus totally dependent on the sale of its labour power for survival." ix As they point out, proletarianisation in the 'Third World' has been a very complex process that has not necessarily created a new working class around the world that looks like the old working class of Britain and western Europe. Munslow and Finch point in particular to two features of proletarianisation under conditions of late development: labour scarcity and extra-economic coercion. ${ }^{\mathrm{x}}$ Their book offers a number of case studies that demonstrate the importance of forced labour mobilisation as a means of dealing with the labour supply problem, and, as they point out, such forced labour lasted until the 1920s in the British colonies, until the end of WWII in the French colonies and until 1961 in the Portuguese colonies. ${ }^{\mathrm{xi}}$ This sort of mobilisation could be carried out either by the state or by private capitalists, but Munslow and Finch are clear about the importance of the state in Third World proletarianisation, noting "the role of the state in accelerating the proletarianisation process, for example by land annexation, taxation or the introduction of forced labour obligations." "xii

It might be expected therefore that the role of extra-economic coercion and the capitalist state in the process of proletarianisation have been universally recognised by Marxist analyses. However, there is a long-running debate about the nature of Marx's notion of 'free wage labour' and whether a proletarian can also be subject to extra-economic coercion, or indeed whether slavery and other forms of unfree labour can be a 'normal' part of capitalist exploitation. Many previous works on proletarianisation have assumed that subsequent processes of working class formation would follow that of England and that only truly 'free' wage labourers could be true proletarians. ${ }^{\text {xiii }}$ In response to this, recent work by Van der Linden has argued that Marx himself was wrong to believe that labour power under capitalism could only be commodified through free wage labour ("as a free individual [who] can dispose of his labour-power as his own commodity"). He argues instead that the history of proletarianisation beyond the North Atlantic region shows that "in reality labour commodification takes many different forms, of which the free wage-earner only selling his or her own labour power is only one example."xiv He goes on to argue that "there is an almost endless variety of producers in capitalism, and the intermediate forms between the different categories are fluid rather than sharply defined." ${ }^{x v}$ As Van der Linden points out, besides outright chattel slavery, there are in fact many ways in which wage workers can be tied to their employers. ${ }^{\text {xvi }}$

However, whether Van der Linden's charges against Marx are entirely justified is another matter. As Banaji has pointed out in his essay, "The Fictions of Free Labour: Contract, Coercion, and so-called Unfree Labour", Marx was fully aware that his conception of free wage labour did not mean that workers under capitalism were free from extra-economic coercion. In fact, Banaji argues, it is impossible under capitalism to clearly draw a line between freedom and coercion. ${ }^{x v i i}$ Banaji terms the idea that wage labour under capitalism is based on a freely-made contract between worker and employer the "liberal-individualist notion of wage-labour". xviii In reality, 
...employers have repeatedly subjected free workers to repressive forms of control. The massive deployment of Polish seasonal labourers on the East Elbian estates during the First World War and under Nazism, the forced recruitment of wage-labourers in French and British Africa, and the position of nineteenth-century English wage-earners who faced criminal sanctions for breach of contract all exemplify situations where the 'boundary between compulsion and free will...was neither distinct nor of any great interest' to the authorities and employers. ${ }^{\text {xix }}$

Thus for Banaji, "at the level of individual capitals, it is accumulation... that defines capitalism, not the presence or absence of 'free' labour," and capital accumulation actually works through "a multiplicity of forms of exploitation based on wage labour." $\mathrm{xx}$ Marx did understand that as proletarianisation spread around the world it would take quite different forms and may involve varying degrees of unfreedom. However, subsequent history has shown just how varied and uneven the process would be, and the extent to which capitalism would rely for certain periods on forced labour.

While the authors discussed above do at least mention the role of the state in proletarianisation, only Munslow and Finch have analysed its role as a key agent of the process. Thus, one of the aims of this study will be to do just that by examining the role of state-led labour mobilisation in midtwentieth century processes of Korean proletarianisation. A second aspect, again rarely mentioned in the literature outlined above, is the role of war, specifically as a period during which the capitalist state enhances all its powers and becomes hyperactive. ${ }^{\mathrm{xxi}}$

The analysis of the Korean case presented in this article will be based on an important theoretical proposition: that both Korea under Japanese colonial rule and the postcolonial Democratic People's Republic of Korea were capitalist societies. While their political regimes appear to have been diametrically opposed, this masks the fact that both represented forms of state capitalist political economy. ${ }^{x i i}$ By state capitalist here I mean societies in which the state either wholly or predominantly took on the task of capital accumulation, acting as a huge capitalist enterprise. This global tendency of early- and mid-twentieth-century capitalism was taken to its extreme form by the countries of the Soviet bloc - including the DPRK - where all (or almost all) private capital accumulation was abolished and a bureaucracy completely replaced the private capitalist class, a form referred to by Cliff as "bureaucratic state capitalism". xxiii However, the internal logic of capitalism, determined by the capital-wage labour relation and the drive for competitive accumulation, remained. During the high period of state capitalism in the mid-twentieth century, military competition between blocs mostly replaced economic competition between capitals as the driver of accumulation for the countries of the Soviet bloc, but the same tendency was present to a lesser degree in other countries too. ${ }^{\text {xiv }}$

Since state capitalism often means that workers are directly exploited and controlled by the state, it has important implications for the wage labour debate and proletarianisation. The forced mobilisation of workers and limitations on their mobility by the state do not negate Marx's notion of capitalist relations of production based on wage labour, but rather represent one of the forms that 
capitalist wage labour can take, especially in the process of initial industrialisation and proletarianisation, and/or in times of war. Rather than a dichotomy of free and unfree labour, this view sees wage labour under capitalism as existing on a spectrum from relatively free to relatively unfree. Just as under bureaucratic state capitalism the competition between many capitals is displaced from the sub-national level but the competitive drive to accumulate is maintained through inter-state and inter-bloc competition, ${ }^{\mathrm{xxv}}$ under forms of state capitalism the labour market is partially or wholly displaced but the fundamental wage labour-capital relation remains as the means by which capital is accumulated. ${ }^{\text {xxvi }}$

The following section of this article will describe in outline the industrialisation of the northern region of Korea between the Japanese invasion of Manchuria in 1931 and the completion of the DPRK's first five-year plan in 1961. Sections 4 and 5 will then look in detail at the question of proletarianisation, treating the periods of late colonial rule (1931-1945) and wartime and post-war DPRK (1945-1961) in separate sections.

\section{The industrialisation of northern Korea under colonial and postcolonial regimes, 1931-1961}

Japan began its drive to industrialise Korea in the early 1930s under Governor-General Ugaki Kazushige. Close cooperation between the Japanese Government-General in Korea and Japanese conglomerates such as Noguchi Jun's Chisso had already begun to take shape in the late 1920s with the planning of huge hydroelectric dams on the Yalu River and the building of Chisso's enormous chemical plant and company town at Hŭngnam on the east coast of northern Korea. However, it was Japan's expansion into Manchuria in 1931 that really served as impetus for industrialising northern Korea and integrating it into the newly-gained colonial territories of northeastern China. ${ }^{x x v i i}$

Before turning to the scale and character of this industrialisation drive, it is necessary to note the situation of the Korean working class prior to 1931. Large-scale proletarianisation had actually begun in Korea (or the Japanese colony of Chōsen as it was then known) not long after annexation with the land survey carried out by the Japanese between 1910 and 1918. This survey helped to enlarge the landholdings of large landlords and dispossess smallholder peasants, increasing the floating population of landless and destitute peasants. This led, in the $1920 \mathrm{~s}$, to the growth of a significant population of wage workers, concentrated especially in the informal sector, but also employed in emerging light industries such as textiles and rubber. ${ }^{\text {xxviii }}$ In 1930 Korea was still an overwhelmingly agricultural country where some 80 percent of the adult male population were employed in farming. However, out of a total population of 21 million, 1.16 million were classified as urban wage workers by the Government-General and of these 40.4 percent were day labourers, 27.6 percent were domestic servants while only 3.4 percent were factory workers and 2 percent miners. ${ }^{\text {xxix }}$ Thus Korea at the time had the sort of small and largely informal working class often seen as typical of colonised countries or postcolonial societies that have yet to achieve significant industrialisation. 
This is the accepted version of an article published by Taylor and Francis in Third World Quarterly, Vol.37 (10), 1901-1920.

Please refer to the published version when citing: http://www.tandfonline.com/doi/full/10.1080/01436597.2016.1171707

Accepted Version downloaded from SOAS Research Online: http://eprints.soas.ac.uk/22708/ 
Table 1: Structure of the Korean urban working class in 1930

\begin{tabular}{l|l}
\hline Category of worker & $\begin{array}{l}\text { Population } \\
\text { (Total population in 1930: 21 million) }\end{array}$ \\
\hline $\begin{array}{l}\text { Day-labourers } \\
\text { (porters, transport workers etc) }\end{array}$ & $468,000(40.4 \%)$ \\
\hline $\begin{array}{l}\text { Domestic servants } \\
\text { (maids and houseboys) }\end{array}$ & $319,000(27.6)$ \\
\hline $\begin{array}{l}\text { Factory workers } \\
\text { (concentrated in food processing) }\end{array}$ & $40,000(3.4 \%)$ \\
\hline Mineworkers & $23,000(2 \%)$ \\
\hline Other & $310,000(26.6 \%)$ \\
\hline Total urban wage workers & $1,160,000$ \\
\hline
\end{tabular}

Source: Park, "Colonial Industrial Growth and the Working Class,” 134.

In the early to mid 1930s, large industrial complexes began to be established in the northern part of the Korean peninsula, alongside an expansion of light industries such as textiles and rubber. Such complexes included the aforementioned Hŭngnam chemical works and the Ch'ŏngjin Iron Works established by Mitsubishi further up the east coast. Overall, the 1930s saw a major change in the structure of Korean industry, with a shift in the ratio of light to heavy industry from 79.3 percent vs 20.7 percent in 1930 to a situation in 1943 where production in each sector was about equal at 50.5 percent to 49.5 percent respectively. ${ }^{\mathrm{xx}}$

The results of this period of rapid industrialisation in terms of proletarianisation were clear. Between 1933 and 1943 the industrial working class employed in factories, mines, transportation and construction grew from around 200,000 to 1.22 million workers and by 1943 workers in these sectors made up 70 percent of the working class as a whole. ${ }^{x x i}$ Along with this proletarianisation came mass migrations of Koreans to new places of work, principally from the agricultural south of the country to the industrialising northern provinces of Pyŏng'an and Hamgyŏng, as well as the industrial centres of the centre and south: Seoul-Inch'ŏn and Pusan. ${ }^{\text {xxxii }}$ Other features of the growth and transformation of Korea's working class during this period included the increasing concentration of workers in larger workplaces, the increasing masculinisation of the workforce, ${ }^{\mathrm{xxxiii}}$ and a decreasing proportion of Japanese workers in Korean factories. ${ }^{\text {xxiv }}$ It should also be noted that the figures quoted above do not encompass the entirety of Korean proletarianisation since in the 1930s many Koreans migrated to Japan and Manchuria to become industrial workers there and that trend would be further extended once the Japanese empire had entered a total war footing in the late 1930s and early 1940s. 
This is the accepted version of an article published by Taylor and Francis in Third World Quarterly, Vol.37 (10), 1901-1920.

Please refer to the published version when citing: http://www.tandfonline.com/doi/full/10.1080/01436597.2016.1171707

Accepted Version downloaded from SOAS Research Online: http://eprints.soas.ac.uk/22708/ 
Table 2: Growth of the Korean industrial working class under Japan's industrialisation policy, 1933-1943

\begin{tabular}{l|l|l}
\hline Category of worker & $\mathbf{1 9 3 3}$ & $\mathbf{1 9 4 3}$ \\
\hline Factory workers & 99,400 & 390,000 \\
\hline Mineworkers & 70,700 & 280,000 \\
\hline Transportation workers & $\mathrm{n} / \mathrm{a}$ & 170,000 \\
\hline Construction workers & 43,600 & 380,000 \\
\hline Miscellaneous & $\mathrm{n} / \mathrm{a}$ & 530,000 \\
\hline Total & $\mathrm{n} / \mathrm{a}$ & $1,750,000$ \\
\hline Sour: Park, Con & & \\
\hline
\end{tabular}

Source: Park, "Colonial Industrial Growth and the Working Class," 140.

In August 1945 as the Japanese surrendered, the northern half of the Korean peninsula was occupied by the Soviet army which set about installing a friendly government under Kim Il Sung. This emerging state under Soviet tutelage inherited 65 percent of Korea's heavy industry, taking over Japanese factories and industrial complexes wholesale and formally nationalising them in $1946 .{ }^{\mathrm{xxxv}}$ Also in the spring of 1946 the nascent North Korean state carried out a sweeping land reform that almost completely dispossessed former Japanese and Korean landlords, creating a small independent peasant economy overnight. ${ }^{\text {xxxvi }}$ In the late 1940s North Korean industry faced problems due to the legacy of the recent war and the division of the peninsula into two hostile states, including the fact that this period saw a significant reversal of the south-north migration of the 1930 s, with some 2 million Koreans moving across the $38^{\text {th }}$ parallel from the north to the south. However, despite these problems the newly nationalised industries of the DPRK were able to recover and even achieve some growth before the outbreak of the Korean War in 1950. ${ }^{\text {xxxvii }}$

The Korean War of 1950-1953 was absolutely devastating to the North Korean economy and to its industrial facilities in particular, which sustained continuous aerial bombardment by the US Air Force for much of the three years. A large proportion of North Korean industry was moved underground in order to continue operating and valuable plant was moved across the border into northern China so that it could be preserved. Although parts of the industrial base were saved in this way, most modern buildings in urban and industrial areas were flattened and so postwar reconstruction meant a literal rebuilding of the built environment of the whole country. ${ }^{\text {xxxviii }}$ This programme of reconstruction, which began as soon as the war ended in the summer of 1953, was supported by a huge injection of money, materials and manpower from the USSR, its Eastern European satellites, and the PRC, which kept its troops in the country until 1958, partly in order to 
aid with rebuilding. ${ }^{\text {xxxix }}$ But while the Three-Year Plan of 1954-1956 remained focused on reconstruction, the Five-Year Plan of $1957-1961^{\mathrm{xl}}$ was much more ambitious, as Kim Il Sung pursued a policy of headlong heavy industrialisation. In doing this he was following what had been, until the mid-1950s, the normal economic policy of both the USSR and its satellites, emphasising the all-round development of the national economy. ${ }^{x l i}$ At the same time, the DPRK pursued a very rapid collectivisation of the agricultural sector, which was completed in 1958, leaving no independent peasant households in the entire country. In terms of extensive growth, the industrialisation drive was successful, with average annual GNI growth of 16.6 percent in the period 1953-1967, while annual growth rates in the late 1950s reached well over 20 percent. ${ }^{\text {xlii }}$ Using the industrial framework ${ }^{\text {xliii }}$ left behind by Japanese colonial development, a huge transfer of capital and technology from the USSR and Eastern Europe and the labour power of newly-proletarianised North Korean workers, the DPRK was able to catapult itself into the position of being the most industrialised East Asian nation aside from Japan by the 1960s.

This inevitably meant a massive expansion of the North Korean working class in both the industrial and non-industrial sectors. According to official DPRK figures, the total number of employees in the economy increased from 565,000 in 1953 to 1.45 million in 1960, out of a total population of 10.78 million. ${ }^{x \text { liv }}$ The increase for industry ${ }^{x l v}$ alone was from $165,000^{x l v i}$ immediately following the Korean War to 699,000 in 1960, and including workers in transportation, communications and construction gives an increase for the broader non-rural working class from 318,000 to 954,000. Meanwhile, during the same period the proportion of all employees in industry (as opposed to agriculture, transport, construction and so on) rose from 29.2 percent to 48.2 percent. ${ }^{\text {xlvii }}$ This new industrial working class was still concentrated in the areas that had begun to be industrialised in the 1930s: Pyongyang (246,000 employees in 1960), the surrounding province of South P'yŏngan (200,000 employees), and the North and South Hamgyŏng Provinces (a total of 343,000 employees). ${ }^{\text {xlviii }}$

Table 3: Number of employees in various branches of the DPRK economy, 1946-1960

\begin{tabular}{l|l|l|l|l|l|l}
\hline $\begin{array}{l}\text { Branch of } \\
\text { productio } \\
\mathbf{n}\end{array}$ & 1946 & 1949 & 1953 & 1956 & 1959 & 1960 \\
\hline Industry & 155,000 & 245,000 & 165,000 & 294,000 & 649,000 & 699,000 \\
\hline $\begin{array}{l}\text { Agriculture } \\
\text { (Only those employed on } \\
\text { state farms) }\end{array}$ & - & 17,000 & 57,000 & 54,000 & 87,000 & 97,000 \\
\hline Transportation & - & - & 49,000 & 55,000 & 68,000 & 72,000 \\
\hline
\end{tabular}


This is the accepted version of an article published by Taylor and Francis in Third World Quarterly, Vol.37 (10), 1901-1920. Please refer to the published version when citing: http://www.tandfonline.com/doi/full/10.1080/01436597.2016.1171707 Accepted Version downloaded from SOAS Research Online: http://eprints.soas.ac.uk/22708/

\begin{tabular}{l|l|l|l|l|l|l} 
Communication & - & - & 13,000 & 13,000 & 14,000 & 15,000 \\
\hline Capital construction & - & 82,000 & 91,000 & 132,000 & 195,000 & 168,000 \\
\hline Trade & - & 25,000 & 17,000 & 36,000 & 85,000 & 81,000 \\
\hline $\begin{array}{l}\text { Non- } \\
\text { production } \\
\text { branches }\end{array}$ & 63,000 & 131,000 & 171,000 & 172,000 & 185,000 & 173,000 \\
\hline
\end{tabular}

Source: Statistical Returns of National Economy of the Democratic People's Republic of Korea, 1946-1960, 125.

Immediately after liberation most new workers in North Korea were poor peasants attracted by new opportunities in industry, but they were also joined by those who had lost out in the land reforms of 1946: former landlords, middling peasants, merchants and so on. After the Korean War the labour supply suffered from severe restrictions while demand for labour skyrocketed and the state had to find new ways to achieve its ambitious expansion of the working class, a subject we will return to in section 5 .

\section{The formation of the north Korean working class I: under colonial rule, 1931-1945}

As the industrialisation of Korea began in earnest in the early 1930s, labour scarcity quickly became a problem for the Japanese conglomerates like Chisso who were investing in the colony with the encouragement of the Government-General. ${ }^{\text {xlix }}$ In the late 1920s and early 1930s it was specifically unskilled labourers that were needed on big projects like the building of hydroelectric dams and the Hŭngnam chemical complex. Initially industrial labour came voluntarily from the peasant class and the informal proletariat of the towns and cities. But by 1934 the problem had become acute enough for the Government-General to step in and organise the first state-led labour recruitment programme in April of that year. This was called the 'policy to transfer the surplus southern population to the northern provinces' (nansen kajō jinkō hokuisaku) and it was designed to encourage unskilled construction workers to migrate from the agricultural southern provinces (Ch'ungch'ŏng, Chŏlla, and Kyŏngsang) to the north of Korea where industrial development was focused. ${ }^{1}$ However, until the late 1930s, there was no significant coercive mobilisation of workers by the state. During much of the 1930s Korea migrant labour continued to move freely around the peninsula, with workers going to the northern industrial areas for periods and then returning to their rural homes in the south.

With the beginning of the Sino-Japanese War in 1937 and the intensification of Japan's colonial industrialisation programme, the Government-General introduced a series of larger and frequently coercive labour mobilisation programmes under the umbrella of the National General Mobilisation Law. According to Brandon Palmer there were three types of labour mobilisation introduced into Korea between 1938 and 1942: company-directed recruitment with state backing (bosh $\bar{u}$ ); 
government-directed recruitment (kan assen); and labour conscription (chōyō). They were brought in in phases but also co-existed and shared some similar features with one another. ${ }^{\text {li }}$

Under the company-directed recruitment system the Government-General gave companies quotas for numbers of workers they could recruit from certain areas. The Government-General also provided help with recruitment on the ground via police stations and government-run labour offices, which frequently took the form of pressure applied to young men and their families. ${ }^{\text {lii }}$ However, it appears that this system was both expensive for companies and failed to recruit the required number of workers for Japanese industry. Thus the Japanese state turned to a more interventionist approach with the government-directed system, under which companies could request workers from the Government-General, which would in turn use employment agencies to fill the demands. Under this system recent graduates and skilled workers aged 18 to 40 were required to register with the government and the major employment agencies were nationalised. This system certainly increased the coerciveness of labour recruitment in colonial Korea, with county authorities ordering village heads to provide a certain number of young men for the recruiters. Between 1939 and 1945 a total of 402,053 Korean men were mobilised under government-directed recruitment to work in both Korea and Japan. Of these, the vast majority were recruited for construction, public works, shipyards and defensive fortifications (83 percent), with 10 percent going to mines and only 2.2 percent to factories. ${ }^{\text {liii }}$ So this type of mobilisation did not create a great many new factory workers and was mainly directed at providing large numbers of unskilled manual workers for wartime projects, replacing Japanese workers who had been mobilised for the military.

The third and most coercive form of labour mobilisation - labour conscription - was introduced into the Korean colony in 1942, after the start of the Pacific War. As Brandon Palmer writes, "Conscription gave the government full control over all aspects of labour, including the power to bind workers to their jobs. Conscripted labourers were national employees and could not quit or change jobs without government permission." "liv Under this system there were two types of conscription: either workers could be recruited (coercively) for a job and fixed in that position for the period of a one or two-year contract, or they could be fixed in their existing job and forbidden from leaving. In fact, within Korea itself conscription usually took the latter form, with whole factories or mines having their workers frozen in position and unable to leave their jobs. ${ }^{\text {lv }}$ Thus, conscription consisted of both forcible proletarianisation of men (and some women) from rural Korean villages and severe restrictions on the movement of workers; a major shift towards the unfree end of the wage labour spectrum in the context of war and labour shortages. During the lifetime of this system (1942-1945) Koreans were conscripted 526,042 times, with 43,679 being requisitioned to new workplaces within Korea and 260,145 being frozen to their positions, while another 222,082 were sent to work in Japan. ${ }^{\text {lvi }}$ One other feature of labour mobilisation that is worth noting is the system of labour passports that the Japanese government established during the war. Under this system workers were issued with two passports, which were required to get a job. One would be held by the employer and the other kept by the worker, thus effectively preventing workers from moving from one workplace to another without the necessary permission. ${ }^{\text {lvii }}$ 
These state-led forms of labour recruitment were undoubtedly one of the main routes for proletarianisation during the latter part of the colonial period in Korea. Overall they recruited very large numbers of Koreans , with a total of 928,095 mobilisations under the government-directed and labour conscription systems. To this can be added the much larger number of men and women who were mobilised for temporary public works and construction projects by semi-official organisations such as the Patriotic Units (K: Aegukpan, J: Aikokuhan), amounting to a total of 4,146,098 mobilisations in the period 1938-1945. . $^{\text {liii }}$ However, since there are no figures for the recruitment of workers by companies outside of these programmes, it is impossible to make a direct comparison of the numbers of Koreans who became workers via official routes as opposed to other routes that did not involve state intervention or wartime mobilisation. It is also necessary to bear in mind that alongside the role of the state, there were several other important factors pushing rural Koreans to move to industrial areas and get jobs in new industries. These included bad conditions in rural areas, especially during the years 1939-1942, as well as more personal factors such as a desire to leave an oppressive family or to get on in the world and take advantage of opportunities not available in rural Korea.

Overall then, it is a fact that a large proportion of Koreans who became workers in the late colonial period did so via some form of state intervention and that the primary motivation for this intervention was mobilisation for war. A second conclusion is that during this period the process of proletarianisation had a decidedly coercive character, ranging from false enticements and socialmoral pressure at one end to outright kidnapping of young Korean men at the most extreme end. Not only this, but the work which newly-recruited Korean workers performed was often far from the ideal of 'free wage labour', with severe restrictions on the movement of labour, strict labour discipline and other phenomena such as forced savings accounts into which workers had to place all their earnings. lix

\section{The formation of the North Korean working class II: under the DPRK, 1945-1961}

In a centralised, bureaucratic state capitalist society like that of the DPRK, where the state takes on the role of capital itself, it stands to reason that the state would be the primary agent in the process of proletarianisation. In fact from the early days of North Korea, even before the official founding of the DPRK in September 1948, it was the avowed aim of the state to proletarianise the whole of Korean society. ${ }^{\mathrm{lx}}$ The state did not simply pursue this aim in a passive way by carrying out its programme of industrialisation and waiting for new workers to sign up for jobs in factories or mines. From the beginning of the Korean War in June 1950 the DPRK state actively mobilised peasants and other sectors of society to become workers in order to overcome the severe labour shortages it faced. Labour shortages which were primarily caused by the war itself and its devastating aftermath. This demonstrates that the process of proletarianisation in North Korea had something in common with both 1930s colonial Korea and with the other Third World cases discussed by Munslow and Finch: labour supply was a key problem for industrialisation and one that had to be solved by extra-economic means. 
This is the accepted version of an article that will be published by Taylor and Francis in Third World Quarterly. Please refer to the published version when citing: http://www.tandfonline.com/loi/ctwq20\#.V5eBs krKUk

Accepted Version downloaded from SOAS Research Online: http://eprints.soas.ac.uk/22708/

In the early years between liberation in 1945 and the Korean War the North Korean economy and working class recovered from the ravages of WWII and the chaos that followed liberation, but neither expanded particularly rapidly. In 1947 the emerging North Korean state put in place its first one-year plan and by 1949 industrial output had recovered to its pre-liberation levels. Although the state needed recruit workers for its recovering industries, the land reform of 1946 made this difficult and as yet there were no attempts to mobilise new layers of workers on a mass scale. ${ }^{1 x i}$ That changed drastically with the outbreak of the Korean War, which, like other wars, immediately caused both high demand for the production of certain goods and severe labour shortages as men of working age were mobilised for frontline fighting. In 1950 the number of industrial workers in North Korea dropped to 82 percent of the 1949 level, dropping further to 62 percent in 1951 before recovering slightly to 74 percent in 1952 . ${ }^{\text {xii }}$ The DPRK state's answer to this problem was the mass mobilisation of most of the North Korean population for the war effort. Of most relevance here are two orders issued by the Military Affairs Commission (Kunsa wiwonhoe) in the first two months of the war: Order no. 6 "On wartime labour" (June 1950) and Order no. 23 "On wartime compulsory labour mobilisation" (July 1950). Labour mobilisation on the basis of these orders was carried out systematically by people's committees and party officials in each county, with the focus on mobilising women, peasants and even boys for work in factories, mines and other industrial facilities. In essence it was a form of labour conscription similar in some ways to the chōyo system used by the Japanese after 1942. Han Sŏng-hun cites the example of Yŏnch'ŏn County in Kangwon Province, where in the early months of the war 12,789 men and 14,812 women were mobilised for compulsory wartime labour duties. ${ }^{\text {lxiii }}$ Han also emphasises the way in which the war served as a means of bringing large numbers of women into the industrial workforce and completely changing their attitudes towards wage labour. In the first three months of the war alone 31,366 women joined the industrial workforce in factories and other enterprises. This influx continued throughout the war, with - for example - some 19,000 women being recruited to work in the factories of North Hamgyŏng Province in June 1951. 1xiv

Although wartime mobilisation had proletarianised many Korean peasants and women and provided a solution for the immediate problem of maintaining production in wartime, it could not overcome the underlying loss of able-bodied and skilled workers to the war. Further causes of the postwar labour shortage were the high demand for labour stemming first from basic reconstruction and then from the heavy industrialisation drive of the five-year plan (1957-1961), and the problem of labour hoarding by enterprises who wanted to keep workers even when they didn't immediately need their labour power. ${ }^{1 \times v}$ The influx of new workers also brought with it new problems, including a slackening of labour discipline among the workforce and a high level of labour mobility as many workers left their workplaces or switched jobs on a regular basis. Thus, after the armistice in July 1953, the North Korean state was faced with a continuing severe labour shortage and a chaotic situation in the factories. ${ }^{\text {lxvi }}$

In order to solve the labour shortage problem the DPRK state by and large continued its wartime mass mobilisation policy into the postwar period. Once the multi-year plans were in operation from 1954, the State Planning Commission would centrally calculate the number of workers required in 
This is the accepted version of an article that will be published by Taylor and Francis in Third World Quarterly. Please refer to the published version when citing: http://www.tandfonline.com/loi/ctwq20\#.V5eBs krKUk

Accepted Version downloaded from SOAS Research Online: http://eprints.soas.ac.uk/22708/

each sector of the economy and then the Ministry of Labour would assign the workers to individual enterprises. At the lower level the workers were assigned to their workplaces by the labour department of the local People's Committee (PC). ${ }^{\text {lxvii }}$ After the war most new workers entering factories and other industrial work were actually discharged soldiers, so in a sense the wartime troop mobilisation transitioned straight into peacetime labour mobilisation: rather than returning to their villages demobbed soldiers were assigned to workplaces. A second large group of new workers came from the peasant class, who were presumably mobilised by PCs on the orders of the Ministry of Labour. This process must have been aided by the programme of agricultural collectivisation that began in earnest in 1954 and was completed by the end of 1958. Although hard data on this is not currently available, it has been suggested that the combination of small independent farms into large collective farms and the beginnings of mechanisation in the countryside during the mid-1950s helped to create a surplus rural population that the state could channel into industrial production. ${ }^{\text {.xviii }}$ Other smaller groups who provided workers for the postwar reconstruction and industrialisation drive included handicraftsmen, petty traders (whose businesses had usually been lost during the war) and young people newly graduated from school. ${ }^{\text {1xix }}$

Besides discharged soldiers, women and the surplus peasant population, the DPRK state had some other sources of labour in the mid-1950s, especially during the Three-Year Plan focusing on reconstruction when large quantities of unskilled labour were required in the construction sector. One such source was the student and office worker population of the capital and other urban areas who were organised into 'volunteer' work brigades during holiday periods in order to speed up construction. ${ }^{1 \mathrm{xx}}$ Another source of labour for reconstruction was the Chinese People's Volunteer Army, which remained stationed in North Korea in large numbers until 1958. There was clearly an understanding between the DPRK and People's Republic of China governments that the labour of the troops stationed in North Korea would constitute a large part of China's fraternal aid to its warstricken ally and it seems that Chinese soldiers from the PRC were particularly put to work in rural areas to help re-start agricultural production. ${ }^{\text {lxxi }}$ No doubt in the early years of postwar reconstruction, when skilled and experienced workers were not so essential (because many factories were not even running yet) and the level of mechanisation was low, these sources of labour were very useful for the DPRK state.

We know that in the postwar period North Korean workers continued to be assigned to their workplaces by the state rather than participating in a labour market as such, but what of their situation once they were working in a factory, mine or other workplace? As noted above, at the end of the war the state faced a situation of flux in the industrial sector with very high rates of labour mobility as well as many new workers with little or no experience in a modern, industrial workplace. The state had begun to tackle this problem during wartime with the Military Affairs Commission orders mentioned above that prohibited workers from leaving their workplace of their own volition and made absence without leave a criminal offence. Far from relaxing these regulations after the armistice, in the immediate postwar period the DPRK government wrote them into law with the August 31, 1953 Supreme People's Assembly ordinance entitled: "On the prohibition of labourers and office workers from leaving their workplaces of their own accord". 
This is the accepted version of an article that will be published by Taylor and Francis in Third World Quarterly. Please refer to the published version when citing: http://www.tandfonline.com/loi/ctwq20\#.V5eBs krKUk

Accepted Version downloaded from SOAS Research Online: http://eprints.soas.ac.uk/22708/

This ordinance stated clearly that "workers who intend to leave their workplace or move to another workplace must get permission from the workplace manager" and "those who intentionally leave their workplace must be brought to trial and can be sentenced to between 6 months and one year of reformative labour by the People's Court."lxxii These restrictions on the movement of workers were enforced through a system of labour passports (rodong such'ǒp) and worker registers (roryǒk taejang) which were kept by each enterprise, rather similar to those used by the Japanese in the early 1940s. Not only did the enterprise record information about all workers in its worker register, it was also required to investigate a worker's labour passport for five days when hiring a new worker. North Korea's newly proletarianised workers were therefore tied to their workplace and highly dependent on their factory or enterprise manager. ${ }^{\text {1xxiii }}$

\section{Conclusion}

As the discussions above illustrate, there were significant similarities between the processes of proletarianisation that took place in colonial Korea under Japanese rule and in postcolonial North Korea. In the following I will attempt to highlight both the similarities and the quite important differences between the two periods and then use that comparison to shed some light on the broader question of twentieth century proletarianisation in the developing world. First though, it should be stressed that while the colonial Japanese regime and the DPRK state had much in common in political economic terms, they were not in any sense equivalent political regimes. The fact that one state was founded on imperialism, racism and exploitation while the other claimed to be a government of national liberation ruling in the interests of the Korean masses was not simply a matter of ideology. These differences in political orientation had significant effects in the 'real world' on the behaviour of leaders, bureaucrats and the mass of people who were their subjects. That is to say, it is likely that many Koreans in 1950s North Korea felt they had a stake in the country and its future and wished to contribute to its defence and its postwar recovery. This difference does need to be borne in mind when we assess the coerciveness of labour mobilisation under the two regimes. The different historical context of the two regimes also requires some attention. Most importantly, once the Soviet Union had occupied northern Korea in 1945 it was in a position to impose many of its labour policies on the territory, and the influence of Stalin-era Soviet labour management would continue in the DPRK for many years. Thus, as in many areas of society, labour policy and the processes of proletarianisation in North Korea reveal a complex mixture of influences from the Japanese colonial period and the USSR. ${ }^{\text {lxiv }}$

Perhaps the most prominent similarity between the types of mobilisation used in colonial and postcolonial North Korea was the use of a state-directed wartime labour conscription system in order to get the required workers for key industries or construction projects. Obviously a key difference lay in the fact that under Japanese state-directed wartime capitalism workers were by and large conscripted by the state to work for private companies, while under the DPRK's bureaucratic state capitalism both recruitment and employment was done by the state as all enterprises were state-owned. In both cases there were also more temporary forms of labour mobilisation through 
This is the accepted version of an article that will be published by Taylor and Francis in Third World Quarterly. Please refer to the published version when citing: http://www.tandfonline.com/loi/ctwq20\#.V5eBs krKUk

Accepted Version downloaded from SOAS Research Online: http://eprints.soas.ac.uk/22708/

semi-official social organisations such as the Patriotic Units of colonial Korea and the mass organisations of the DPRK such as the Democratic Youth League and the Korean Workers' Party.

In terms of where the new workers came from there were both similarities and differences. In both colonial Korea and postcolonial North Korea the primary source of new workers was undoubtedly the peasant class and particularly young men from rural areas. While there were often significant push factors driving this section of the population to seek work in the new industries and in cities, the severe labour shortages experienced in both periods demonstrate that such factors did not convince enough young men to leave their villages and families behind. Coercion directed against the rural population was therefore seen as a necessity in both colonial and postcolonial Korea. But in the postwar DPRK there was a further factor that seems to have been creating a surplus population in rural areas: the programme of collectivisation that was carried out in the mid 1950s. This is a good demonstration of the more comprehensive power of the state in North Korea, as it was able to both directly conscript new workers and consciously create the conditions under which they were no longer required in the agricultural sector.

In the gendering of proletarianisation there was also a notable difference between colonial Korea and the DPRK. Large numbers of women were mobilised by the Japanese state during wartime for various kinds of work - most infamously for forced military prostitution - but they were not mobilised in large numbers to work in industry and the industrial workforce of late colonial Korea actually became more masculine as the proportion of heavy industry rose. By contrast, under North Korea's wartime and postwar mobilisation women became a crucial segment of the population mobilised for industrial work. Whereas the Japanese turned to Korean men to replace Japanese men who had been sent to fight at the front, the DPRK state had little choice but to turn to Korean women to replace the Korean men who had joined the KPA during the Korean War. This wartime and postwar trend in North Korea was driven by both desperate need, due to a severe shortage of working age men, and by the ideology of the DPRK that strongly asserted the equality of women in many areas of public life. ${ }^{1 \mathrm{xxv}}$ Another source of new workers used extensively by the North Korean state after the Korean War was demobbed soldiers, who transitioned from wartime military mobilisation to peacetime industrial deployment. This was a source of labourers that had not been available to the Japanese authorities.

The process of proletarianisation did not end with the recruitment of workers to new industrial jobs. Both states faced the problem of labour mobility; essentially a form of passive resistance on the part of workers who voted with their feet when tired of poor conditions or pay. Thus the Japanese colonial state and the DPRK sought ways to fix Korean workers in their positions and prevent them from either moving to other workplaces or returning to their villages and families. And in both cases the solutions were quite similar: they legislated to prevent workers from leaving their workplaces and introduced bureaucratic measures - in the form of labour passports - to restrict their mobility and gather data on all workers under the purview of the state. In fact in this particular area there seems to be very little difference between the approach of the two states and, while it is certain that the DPRK approach to this issue was heavily influenced by Soviet labour law, it is quite possible 
that some influence also came from practices of the late Japanese colonial period. What is different is that while the fixing of workers in position was a form of wartime conscription under Japanese rule, under the DPRK it only became fully established in law after the end of the Korean War, thus making it a 'normal' rather than 'extraordinary' mode of state-labour relations. Disciplining as well as immobilising the newly-formed workforce was also a common concern of the state in both periods examined here, but this topic is beyond the scope of this article.

In Korea during the period from the start of the Sino-Japanese War in 1937 to the end of the first five-year plan in 1960, a large proportion, possibly even an outright majority, of those who became industrial workers did so through the intervention of the state. This was true across two very different political regimes because the political economies of both these regimes were characterised by states that either dominated and directed capital or took its place entirely. The tendency towards state capitalism, in its different forms, was extremely widespread in the mid-twentieth century and it should not be surprising that otherwise disparate polities should develop similar political-economic structures, especially when we bear in mind that state capitalism was advancing even in industrially developed European countries such as Britain. But two other factors were at work in Korea during this period. First, both the colonial Japanese regime and the DPRK state were practising accelerated catch-up development in northern Korea and direct state intervention was particularly well suited to this sort of development. And second, both regimes were involved in fighting 'total wars' which required mobilisation of the entire population. War then, became the crucial factor in both cases that cemented state control of the economy and motivated the very direct state intervention in the process of creating a new working class.

Marx had already recognised in Capital that the state and coercion were part and parcel of the creation of the working class during the "historic genesis of capitalism", but the implication in his work was that this would sooner or later give way to "the dull compulsion of economic relations". Now, there is ample evidence to argue that proletarianisation has never been a "natural" process led by the expansion of capitalist markets, but rather a process in which the state plays a key role in all societies. Moreover, in mid-twentieth-century developing countries like Korea, wracked by imperialism and total war, the role of the state in proletarianisation would turn out to be far more far-reaching and long-lasting than Marx could have imagined when he was writing in the mid nineteenth century. ${ }^{\text {lxxvi }}$ Comparing the case of Korea to other newly-industrialising countries during the same historical period will no doubt provide rich material for further developing our understanding of proletarianisation under conditions of late development. 
This is the accepted version of an article that will be published by Taylor and Francis in Third World Quarterly. Please refer to the published version when citing: http://www.tandfonline.com/loi/ctwq20\#.V5eBs krKUk

Accepted Version downloaded from SOAS Research Online: http://eprints.soas.ac.uk/22708/

\section{Bibliography}

Armstrong, Charles K. 2004. The North Korean Revolution, 1945-1950. Ithaca: Cornell University Press.

2013. Tyranny of the Weak: North Korea and the World, 1950-1992. Ithaca: Cornell University Press.

Banaji, Jairus 2010. "The Fictions of Free Labour: Contract, Coercion and so-called Unfree Labour.” In Banaji, Theory as History: Essays on Modes of Production and Exploitation. Leiden: Brill.

Binns, Peter 1987. “The Theory of State Capitalism”. In: Russia: From Worker's State to State Capitalism, 73-98.

Central Intelligence Agency National Foreign Assessment Center 1978. "Korea: The Economic Race Between the North and the South”. Washington D.C.: The Agency.

Chung, Joseph Sang-hoon 1974. The North Korean Economy: Structure and Development. Hoover Institution Press, Stanford, California.

Cliff, Tony 1988 [1955]. State Capitalism in Russia. London: Bookmarks.

Cramer, Christopher 1998. "“Civil War is Not a Stupid Thing”: exploring growth, distribution and conflict linkages", SOAS Department of Economics Working Paper Series 73.

Cumings, Bruce 1984. "The origins and development of the Northeast Asian political economy: industrial sectors, product cycles, and political consequences", International Organization 38, $1-40$.

Dunayevskaya, Raya 1988. Marxism and Freedom from 1776 until Today. New York: Columbia University Press.

Gluckstein, Ygael [Tony Cliff] 1957. Mao's China: Economic and political survey. London: George Allen \& Unwin Ltd.

Ha Chaeryong 1997. "Pukhan sanŏphwa wa nodong chŏngch'aek”[North Korean industrialisation and labour policy], Nodong munje nonjip 14.

Han Sŏnghun 2012. Chŏnjaeng kwa inmin: Pukhan sahoejuŭi ch'eje ŭi sŏllip kwa inmin ŭi t'ansaeng [War and the People: The establishment of the North Korean socialist system and the birth of the 'people']. P'aju: Dolbegae.

Harman, Chris 1991. "The state and capitalism today." International Socialism, 2 (51): 3-57.

Kim Cheehyung 2010. The Furnace is Breathing: Work and Everyday Life in North Korea, 19531961. PhD Thesis, Columbia University.

Kim, Janice C. H. 2009. To Live to Work: Factory Women in Colonial Korea, 1910-1945. Stanford: Stanford University Press.

Kim Seongbo 2005. "The Decision-Making Process and Implementation of the North Korean Land Reform." In: Pang and Shin (eds), Landlords, Peasants \& Intellectuals in Modern Korea.

Kim Yŏnchŏl 1998. “1950 nyŏndae pukhan ŭi nodong chŏngch'aek kwa nodongja.” [Workers and North Korea's labour policy in the 1950s]. In: Yŏksa munje yŏn'guso, 1950 nyŏndae nambukhan ŭi sŏnt'aek kwa kulchŏl, 387-409.

Lee Chong-shik 1963. "Land Reform, Collectivisation and the Peasants in North Korea." The China 
This is the accepted version of an article that will be published by Taylor and Francis in Third World Quarterly. Please refer to the published version when citing: http://www.tandfonline.com/loi/ctwq20\#.V5eBs krKUk

Accepted Version downloaded from SOAS Research Online: http://eprints.soas.ac.uk/22708/

Quarterly 14, 65-81.

Marx, Karl 1887. Capital vol I. London: Lawrence and Wishart.

Munslow, B. and Finch, H. (eds) 1984. Proletarianisation in the Third World: Studies in the Creation of a Labour Force Under Dependent Capitalism. London: Croom Helm.

Palmer, Brandon 2013. Fighting for the Enemy: Koreans in Japan's War, 1937-1945. Seattle: University of Washington Press.

Park Soon-Won 1999. Colonial Industrialization and Labor in Korea. Cambridge (MA): Harvard University Asia Center.

1999. "Colonial industrial growth and the emergence of the Korean working class”, in Shin and Robinson, Colonial Modernity in Korea. Cambridge (MA): Harvard University Asia Center.

Rioux, Sebastien 2013. "The Fiction of Economic Coercion: Political Marxism and the Separation of Theory and History." Historical Materialism, 21.4,92-128.

Van der Linden, Marcel 2008. Workers of the World: Essays toward a Global Labour History. Leiden: Brill.

2007. Western Marxism and the Soviet Union. Leiden: Brill.

Van Ree, Eric 1989. "Limits of Juche: North Korea's dependence on Soviet industrial aid, 1953-76", Journal of Communist Studies, 5:1, 50-73.

World Bank 1993. The East Asian Miracle: Economic Growth and Public Policy. New York: Oxford University Press.

Yang Munsu 2001. Pukhan kyŏngje ŭi kujo: kyŏngje kaebal kwa ch'imch'e ŭi mek'önijŭm [The structure of the North Korean economy: the mechanisms of economic development and stagnation] Seoul: SNU Press.

See for example: The World Bank, The East Asian Miracle.

ii For reasons of space and focus the question of worker resistance and organisation will not be addressed in this article. It is nonetheless an integral and important part of the story of proletarianisation and economic development on the Korean peninsula and the author plans to address this in further research.

Marx, Capital I, 500.

Marx, Capital I, 501.

Marx, Capital I, 516.

vi Marx, Capital I, 501. Trotsky later developed this aspect of Marx's insights further in his polemics against the Second International Marxists.

vii Marx, Capital I, 516.

viii Marx, Capital I, 516.

ix Munslow and Finch, Proletarianisation in the Third World, 1.

$\mathrm{x}$ Munslow and Finch, Proletarianisation in the Third World, 1-2.

xi Munslow and Finch, Proletarianisation in the Third World, 4.

xii Munslow and Finch, Proletarianisation in the Third World, 12.

xiii See Rioux, "The Fiction of Economic Coercion" for a critique of the Political Marxist account of the establishment of 'free wage labour' under capitalism. 
xiv Van der Linden, Workers of the World, 20.

xv Van der Linden, Workers of the World, 22.

${ }^{\text {xvi }}$ Van der Linden lists debt bondage, indentured labour, certificates of leave, physical compulsion (locking up workers in company compounds), social security provisions and special benefits, and social or economic connections between employer and employee outside the employment relationship as some of the main forms of ties.

xvii Banaji, "The Fictions of Free Labour", 134.

xviii Banaji, "The Fictions of Free Labour", 137.

xix Banaji, "The Fictions of Free Labour", 142.

xx Banaji, "The Fictions of Free Labour", 145.

${ }^{\mathrm{xxi}}$ Christopher Cramer does discuss the role of war and conflict in development, see: “"“Civil War is Not a Stupid Thing"", 19-22.

xxii The similarity of capitalist developmental states and 'communist' states has been pointed out frequently, often by scholars who would not subscribe to any verison of state capitalism theory. See for example, Philip McMichael, who has written, "although the two political blocs subscribed to opposing representations of human destiny, they shared the same modernist paradigm. National industrialisation would be the vehicle of development in each" (McMichael, Development and Social Change, 30).

xxiii On the distinction between state capitalism and bureaucratic state capitalism, Cliff wrote: "To say that Russia is state capitalist is perfectly correct, but not sufficient; it is also necessary to point out the differences in the juridical relations between the ruling class in Russia and that in a state capitalism which evolved gradually from monopoly capitalism. The most precise name for the Russian society is therefore Bureaucratic State Capitalism." (State Capitalism in Russia, 182).

${ }^{\text {xxiv }}$ For what is considered to be the classic statement of state capitalism theory in relation to the USSR, see Cliff, State Capitalism in Russia. In a similar vein see also: Binns, "The Theory of State Capitalism"; Harman, "The state and capitalism today". For an overview of a variety of theories of state capitalism in relation to the USSR see: Van der Linden, Western Marxism and the Soviet Union, 49-63, 107-126, 180-193, 258-280. For early applications of state capitalism theory to the East Asian context see: Dunayevskaya, Marxism and Freedom, 288-330; Cliff, State Capitalism in Russia, 247-251; Ygael Gluckstein [Tony Cliff], Mao's China. For a more recent and rather different take on state capitalism and China see: Gabriel, Resnick and Wolff, "What Happened to Chinese Communism".

xxv On state capitalism, military competition and accumulation, see Harman, "The state and capitalism today".

xxvi This statement requires some qualification however, since it is not the case even in the most bureaucratic state capitalism like North Korea that the freedom of labour was completely removed. It can be shown that even in these cases workers retained some degree of mobility and a sort of covert labour market did exist as enterprises competed to recruit and retain good workers and the state as a whole sought to raise productivity by incentivising workers through wage differentials and other benefits. See: Kim Yŏnchŏl, “1950 nyondae pukhan”.

xxvii Cumings, "The origins and development".

xxviii See: Kim, To Live, To Work.

xxix Park Soon-won, Colonial Industrialization and Labor, 14.

xxx Park Soon-won, The Emergence of a Factory Labour Force, 51.

xxxi Park Soon-won, Colonial Industrialization and Labor, 29.

xxxii Park Soon-Won, Colonial Industrialization and Labor, 16-18.

xxxiii According to Park the female factory workforce peaked at 45 percent in 1932 and declined to 33 percent in the late 1930s. (Park Soon-won, "Colonial industrial growth", 141).

xxxiv Park Soon-won, "Colonial industrial growth", 141.

${ }_{\mathrm{xxxv}}$ The figure of 65 percent comes from: CIA National Foreign Assessment Center, "Korea: The Economic Race", 1.

${ }^{x x x v i}$ On the land reforms of March 1946 see: Armstrong, The North Korean Revolution, 74-86; Kim, "The DecisionMaking Process."

xxxvii According to official DPRK statistics published in 1960, national income doubled between 1945 and 1949. Although we may want to be sceptical about published North Korean statistics, this sort of growth is not unfeasible since Korea's economy and industrial facilities would have been in a parlous state at the time of liberation in 1945 due to the overall economic situation of Japan towards the end of the Pacific War. See: Central Statistical Board, Statistical Returns, 24.

xxxviii Szalontai, "The Four Horsemen of the Apocalypse", xviii.

xxxix Van Ree, "The Limits of Juche", 58-61.

xl Actually said to have been completed a year early in 1960 .

xli Van Ree, "The Limits of Juche", 55.

xlii For a comparison and discussion of DPRK economic growth figures see: Yang Munsu, Pukhan kyŏngje ui kujo, 26- 
29.

xliii Since so much was destroyed by the Korean War, there is some debate over what the DPRK actually gained from Japan's industrialisation of northern Korea. However, while buildings were destroyed it is clear that much remained for the North Koreans to build on: industrial sites, infrastructure, industrial plant saved by being moved across the border into China, technical expertise, blueprints and so on.

xliv This is the population figure for 1960. In 1953, shortly after the Korean War, the population of the DPRK had been 8.491 million. See: Central Statistical Board, Statistical Returns, 16.

xlv The statistical booklet published by the DPRK in 1960, from which these figures come, does not elucidate how it categorises the various branches of the economy that it uses to divide up the workforce. Presumably the category 'Industry' here means all forms ofmanufacturing.

xlvi The figure of 165,000 immediately following the war seems very low when compared with the figure of 1.22 million for the industrial working class in 1943. This can be explained by a number of factors. The categories used in the sources are different so the figure of 318,000 for 1953 (combining workers in industry, transportation, communications and construction) is the one that should be compared to the 1943 figure. It is also necessary to take into account the fact that while heavy industry was concentrated in the north, at the time of division South Korea had a much higher population and around two-thirds of the Korean working class. An additional factor that explains the low figure for industrial workers in 1953 was the war, which devastated North Korea's industrial facilities and killed large numbers of working age men.

xlvii Central Statistical Board, Statistical Returns, 125.

${ }^{x l v i i i}$ Central Statistical Board, Statistical Returns, 128. The complete elimination of the old independent peasant class in the 1950 s raises the question of whether the peasantry was also proletarianised by collectivisation. In other words, it may be possible to see the sharecropping of cooperative farmers as a form of wage labour as Banaji has suggested. See Banaji, "The Fictions of Free Labour", 145.

${ }^{x l i x}$ It should be noted that by the 1930s there was already a long history of recruiting Koreans as workers for Japanese industries, dating back to the 1910s. See the interesting discussion in Kawashima, The Proletarian Gamble, 28-43.

1 Park Soon-won, Colonial Industrialization, 38-9.

li Palmer, Fighting for the Enemy, 141.

lii Palmer, Fighting for the Enemy, 142.

liii Palmer, Fighting for the Enemy, 144.

liv Palmer, Fighting for the Enemy, 145.

lv Palmer notes that 73 factories and 56 mines in Korea were conscripted by the Government-General in February 1943. (Palmer, ibid, 146).

lvi Palmer, Fighting for the Enemy, 146-7.

lvii Palmer, Fighting for the Enemy, 150.

lviii Palmer, Fighting for the Enemy, 158. It should be emphasised that this figure does not represent a total of individuals mobilised but a total number of mobilisations and many Koreans would have been mobilised multiple times during the course of the war. Many of those who were mobilised were not proletarianised in any real sense as they may have only been mobilised for a few days or weeks for infrastructure work before returning to their rural homes and farming occupations.

lix Palmer, Fighting for the Enemy, 152-5.

lx On North Korea's conscious creation of a working class both 'in itself' and 'for itself', see Armstrong, The North Korean Revolution, 86-92.

lxi According to official statistics, as a proportion of the total population workers increased from 12.5 percent in 1946 to 19 percent at the end of 1949, Central Statistical Board, Statistical Returns, 17. See also: Armstrong, The North Korean Revolution, 160.

lxii Han Sŏnghun, Chonjaeng kwa inmin, 82.

1xiii Han Sŏnghun, Chonjaeng kwa inmin, 80; Kim Yŏn-chŏl, “1950 nyondae pukhan,” 394; Kim Cheehyung, The Furnace is Breathing, 39-47.

lxiv Han Sŏnghun, Chonjaeng kwa inmin, 90-91.

lxv Kim Yŏnchŏl, "1950 nyondae pukhan," 390

lxvi Kim Yŏnchŏl, "1950 nyondae pukhan," 391-2; Ha Chaeryong, "Pukhan sanŏphwa," 83.

lxvii Ha Chaeryong, "Pukhan sanŏphwa", 84.

lxviii On the DPRK's rural collectivisation programme, see Lee Chong-sik, "Land Reform."

lxix Kim Yŏnchŏl, "1950 nyondae pukhan,” 392-3.

lxx The North Korean government actually took great pride in its use of this sort of labour, showing pictures of Pyongyang citizens working on the reconstruction of their city in publicity materials such as the photo album Democratic People's Republic of Korea (1958). This form of mobilisation continues today in the DPRK. 
lxxi Armstrong, Tyranny of the Weak, 57.

lxxii Kim Yŏnchŏl, “1950 nyondae pukhan,”394-5.

lxxiii Kim Yŏnchŏl, "1950 nyondae pukhan,” 394.

${ }^{\text {lxxiv }}$ For a discussion of the mixing of Japanese and Soviet influences in North Korea see: Armstrong, The North Korean Revolution, 191; 242-243.

${ }^{\mathrm{lxxv}}$ In practice the formal, legal equality established in the early DPRK largely meant the equal right to be exploited by the state.

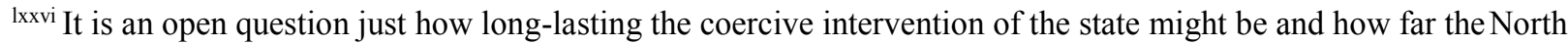
Korean case might be typical of developing countries in the mid-to-late twentieth century. While deep state intervention in proletarianisation might be the norm in the earlier stages of late industrialisation, some would argue that all capitalist societies tend to move towards Marx's ideal type in which 'free wage labour' becomes dominant. This goes to the question of how far the state capitalist regimes were/are a 'normal' part of capitalism or a historically limited aberration. However, this question is beyond the scope of this article. 